$\begin{array}{cl}\text { Türkiye Tarımsal Araştırmalar Dergisi } & \text { Turk J Agric Res } \\ \text { dergipark.gov.tr/tutad } & \text { 2018, 5(2): 103-115 } \\ \text { O TÜTAD } & \text { ISSN: 2148-2306 } \\ \text { e-ISSN: 2528-858X } \\ \text { doi: 10.19159/tutad.361237 }\end{array}$

\title{
Dicle Havzası Toprak Özelliklerinin Yersel Değişimlerinin Jeoistatistik ve Coğrafi Bilgi Sistemleri ile Belirlenmesi ve Haritalanması
}

\author{
Mesut BUDAK ${ }^{*}$, Hikmet GÜNAL ${ }^{2}$, İsmail ÇELIIK ${ }^{3}$, Nurullah ACIR ${ }^{4}$, Mesut SIRRI $^{5}$

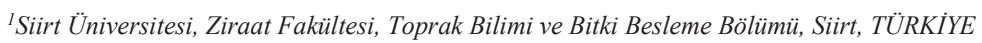 \\ ${ }^{2}$ Gaziosmanpaşa Üniversitesi, Ziraat Fakültesi, Toprak Bilimi ve Bitki Besleme Bölümü, Tokat, TÜRKIYE \\ ${ }^{3}$ Çukurova Üniversitesi, Ziraat Fakültesi, Toprak Bilimi ve Bitki Besleme Bölümü, Adana, TÜRKIYYE \\ ${ }^{4}$ Ahi Evran Üniversitesi, Ziraat Fakültesi, Toprak Bilimi ve Bitki Besleme Bölümü, Kırşehir, TÜRKİYE \\ ${ }^{5}$ Siirt Üniversitesi, Eruh Meslek Yüksekokulu, Organik Tarım Bölümü, Eruh-Siirt, TÜRKIYE
}

\begin{tabular}{|c|c|}
\hline Geliş Tarihi/Received: 04.12.2017 & Kabul Tarihi/Accepted: 12.03 .2018 \\
\hline \multicolumn{2}{|l|}{ ORCID ID (Yazar sirasına göre / by author order) } \\
\hline \multicolumn{2}{|c|}{ (D)orcid.org/0000-0001-5715-1246 (D)orcid.org/0000-0002-4648-2645 (iD)orcid.org/0000-0002-8650-2639 (D)orcid.org/0000-0001-7591-0496 } \\
\hline (D)orcid.org/0000-0001-9793-9599 & \\
\hline
\end{tabular}

Özet: Toprak özelliklerinin mesafeye bağlı değişkenliklerinin belirlenmesi, incelenmesi ve haritalanması yoğun tarımsal üretim yapılan arazilerde uygun amenajmanların geliştirilmesi ve üretimin sürdürülebilirliğinin sağlanması açısından son derece önemlidir. $\mathrm{Bu}$ çalışmada ülkemizin su rezervlerinin büyük bir kısmının yer aldığı, önemli sulama projelerinin gerçekleşmekte olduğu Dicle Havzası'nda bir kısım fiziksel ve kimyasal toprak özellikleri belirlenmiş, mesafeye bağlı değiş̧enlikleri modellenmiş ve haritalanmıştır. Toprak örneklemeleri, Diyarbakır ile Siirt illeri arasında 5 x $5 \mathrm{~km}$ gridlere ayrılmış $4.341 \mathrm{~km}^{2}$ lik alanda her gridin yaklaşık köşesinden toplam 175 noktada $0-20 \mathrm{~cm}$ derinlikten alınmıştır. Toprak özelliklerinin 5 km'den kısa mesafelerdeki değişimlerinin daha doğru tahmin edilebilmesi amacıyla ardışık iki gridin köșe noktaları arasında $250 \mathrm{~m}, 750 \mathrm{~m}$ ve $1750 \mathrm{~m}$ mesafelerden de 33 toprak örneği alınmıştır. Alınan bozulmuş örneklerin tekstür (kum, kil ve silt), organik madde, kireç, toprak reaksiyonu, elektriksel iletkenlik, alınabilir fosfor ve potasyum analizleri yapılmıştır. Mesafeye bağlı değişkenliğ̣in modellenmesi ile örneklenme yapılmayan noktaların ilgili özellikleri tahmin edilmiş ve yersel değişim haritaları oluşturulmuştur. Çalışma alanında en düşük değişkenliğin $\mathrm{pH}(\% \mathrm{VK}=3.9)$ ve en yüksek değiş̧kenliğin ise alınabilir fosfor (\% VK= 137.77) konsantrasyonunda olduğu görülmüştür. En yüksek range değerine sahip toprak özelliği elektriksel iletkenlik (135.4 km) iken en küçük range değeri pH (4.74 km) için elde edilmiştir. Her bir özelliğin en düşük ve en yüksek olduğu yerlerin rahatlıkla tespit edilebildiği toprak haritaları, uygun amenajman yöntemlerinin belirlenmesi, sorunların giderilmesi ve girdilerin en uygun kullanımı açısından son derece yararlı araçlardır.

Anahtar Kelimeler: Dicle Havzası toprakları, jeoistatistik, yersel değişim, semivariogram, toprak amenajmanı

\section{Characterizing Spatial Variability of Soil Properties in Tigris Basin Using Geostatistics and Geographical Information Systems}

\footnotetext{
Abstract: Assessment, evaluation and mapping of the spatial characteristics of soil properties are crucial to ensure the sustainability of plant production and the development of appropriate management practices in the areas of intensive agricultural production. In this study, some physical and chemical soil characteristics of Dicle Basin, where most of the water reserves of our country are located, and large irrigation projects are taking place, were determined and spatial distributions are modeled and mapped. One hundred seventy-five soil samples from Diyarbakır and Siirt provinces were collected from 0-20 $\mathrm{cm}$ depth at approximate corners of each $5 \times 5 \mathrm{~km}$ grids. Coverage of study area was $4.341 \mathrm{~km}^{2}$. In order to make a more accurate estimation of the changes of soil properties at distances shorter than $5 \mathrm{~km}, 33$ soil samples were taken at $250 \mathrm{~m}, 750$ $\mathrm{m}$ and $1750 \mathrm{~m}$ distances between two consecutive grid points. Soil samples were analyzed for texture (sand, clay and silt contents), organic matter $(\mathrm{OM})$, lime content, soil reaction $(\mathrm{pH})$, electrical conductivity $(\mathrm{EC})$, available phosphorus and extractable potassium $(\mathrm{K})$. The modeling of spatial variability allowed to predict the soil characteristics of locations that were
} 
not sampled and spatial distribution maps was created. The lowest variability in the study area was found for $\mathrm{pH}(\mathrm{CV}=3.9 \%)$ and the highest variability was on available phosphorus $(\mathrm{CV}=137.8 \%)$ concentration. The highest range value was obtained for EC $(135.4 \mathrm{~km})$ while the smallest range value was obtained for $\mathrm{pH}(4.74 \mathrm{~km})$. The soil maps where the lowest and highest values of each soil characteristic can be easily detected are extremely useful to determine appropriate management methods, remediate problems and optimize the use of inputs.

Keywords: Tigris Basin soils, geostatistics, spatial variability, semivariogram, soil management

\section{Giriş}

Dicle Havzası, medeniyetin beşiği ve en önemli ekosistemlerinden biri olarak kabul edilen tarihi Mezopotamya'nın kuzey batısında yer almaktadır. Çok uzun yıllardır insanlara ev sahipliği yapan bu bölgelerde, suyun yeterli olması nedeni ile insanlar tarımsal üretim yaparak gida ve giyecek ihtiyaçlarını karşılamışlardır. Aralıksız devam eden tarımsal faaliyetler, dünyanın birçok yerinde olduğu gibi arazi bozulması nedeni ile Dicle Havzası'nın üretkenliğini önemli düzeyde tehdit etmeye başlamıştır. Toprak özellikleri ve yetiştirilecek ürün dikkate alınmadan gerçekleştirilen mekanizasyon, uygun olmayan rotasyon veya mono kültür tarım, organik madde ve besin elementlerinin aşırı sömürülmesinden kaynaklanan yetersizlikler, anız yakılması ile oluşan biyoçeşitliliğin azalması, toprak analizi yapılmadan uygulanan gübreleme ile bir kısım arazilerde aşırı besin elementi birikimi gibi sorunların yanı sira arazilerin yeteneklerine göre kullanılmamaları; Dicle Havzası'nda erozyondan toprak kirlenmesine, arazi bozulmasından çölleşmeye varan çeşitli sorunların ortaya çıkmasına yol açmıştır. İnsan kaynaklı baskılar sonucu ortaya çıkan sorunların azaltılması ve ortadan kaldırılmaları ise sorunların doğru teşhis edilebilmesi ve gerekli tedbirlerin zamanında alınabilmesi ile mümkün olabilir (Salvati ve ark., 2016).

Ana materyal, topoğrafya, zaman ve iklim gibi genetik faktörlerin yanı sıra; toprak işleme, sulama, gübreleme ve hasat gibi uygulamaların etkileri toprakların farklılaşmasına neden olmaktadır. Genetik ve insan kaynaklı etkiler birçok toprak özelliğinin çok kısa mesafelerden ( $\mathrm{mm}$ veya $\mathrm{cm}$ gibi) çok uzun mesafelere (km gibi) kadar değişim göstermelerine yol açmaktadır (Webster ve Oliver, 2007). Tarım arazilerinde fiziksel ve kimyasal toprak özelliklerinin mesafeye bağlı olarak değişim göstermesi bir tarla ölçeğinde dahi bitkisel üretimin arazi içerisinde önemli düzeyde farklılaşmasına neden olmaktadir (Cambardella ve ark., 1994; Budak, 2012; Glendell ve ark., 2014; Vasu ve ark., 2017). $\mathrm{Bu}$ nedenle, toprak verimliliği göstergelerinin yersel değişkenliği hakkında elde edilen bilgiler, toprakta optimum besin statüsünün korunması ve diğer önemli tarımsal uygulamaların idaresi için arazi sahiplerine oldukça faydalı bilgiler sunabilmektedir (Mali ve ark., 2016).
Toprağın fiziksel ve kimyasal özelliklerine ait mesafeye bağlı değişimlerinin belirlenmesi, incelenmesi ve haritalanması uygun amenajman yöntemlerinin geliştirilmesi ve sürdürülebilirliği açısından oldukça önemlidir (Denton ve ark., 2017). Elde edilen haritalarda toprak özelliklerinin en küçük ve en yüksek değerleri ile ortalama değerlerinin yerlerini tespit etmek mümkün olduğundan, sorunlu olduğuna karar verilen alanlar için daha hızlı karar almak mümkün olacaktır (Mali ve ark., 2016). Ancak çalışılan alanın geniş ve yersel değişkenliğin de yüksek olması durumunda, daha doğru tahmin yapabilmek için alınması gereken örnek sayısının arttırılması gerekecektir. $\mathrm{Bu}$ durum yapılacak arazi çalışmalarında daha yüksek maliyet, işgücü ve zaman gereksinimine neden olmaktadır. Bu nedenle, daha az örnekle toprak özelliklerinin mesafeye bağlı değişkenliğini tahmin edecek ve haritalanmalarına yardımcı olacak yöntemlerin geliştirilmesine gereksinim duyulmaktadır (Weindorf ve Zhu, 2010).

Toprak özelliklerinin mesafeye bağlı değişkenliklerinin modellenmesi ve örnekleme mesafeleri ile özellikler arasındaki ilişkinin tanımlanmasında birçok araştırmacı güvenirliliği ispatlanmış olan jeoistatistiksel yöntemleri kullanmışlardır (Goovaerts, 1998; Webster ve Oliver, 2007; Erdem ve ark., 2012; Günal ve ark., 2012; Glendell ve ark., 2014; Sabeti ve ark., 2017; Cao ve ark.,2017; Denton ve ark., 2017; Vasu ve ark., 2017). Jeoistatistikte, toprak özelliklerinin arazideki değişkenliğinin tanımlanması ve modellenmesinde semivariogram modeli, örneklenmeyen noktalara ait değerlerin güvenilir bir aralıkta tahmin edilmesinde ise krigleme yöntemi yaygın olarak kullanılmaktadır (Kalivas ve ark., 2002; Webster ve Oliver, 2007; Barik ve ark., 2014; Tripathi ve ark., 2015; Denton ve ark., 2017).

Ülkemizin önemli su kaynaklarının yer aldığı ve geniş çapta sulama projelerinin uygulandığı Dicle Havzası'nda toprak özelliklerinin mesafeye bağlı değişkenliği konusunda yapılmış çalışmaların sayısı yok denecek kadar azdır. Bölge koşullarının zorluğu nedeni ile yapılamayan çalışmaların eksikliği, ülke tarımı için önemli bir yere sahip tarım arazilerimizin yer aldığı havza ile ilgili planlamaların güvenirliliğini etkilemektedir. Yağışın buharlaşmaya kıyasla oldukça düşük olduğu bölgelerde sulama başlangıçta tarımsal 
üretimin artmasina neden olsa da, uygun olmayan amenajman yöntemlerinin uygulanması zamanla arazilerde tuzluluk ve sodiklik gibi üretimi kısıtlayıcı sorunların ortaya çıkmasına neden olabilir. Bu çalışmanın amacı, sulama ile birlikte önemli bir kısmında tarımsal üretimin yapılmaya başlandığı Dicle Havzası'nda verimlilik açısından önemli olan bazı toprak özelliklerinin yersel değişimlerini jeoistatistiksel yöntemlerle tanımlamak, tahmin etmek ve Coğrafi Bilgi Sistemi (CBS) tekniklerini kullanarak haritalamaktır.

\section{Materyal ve Yöntem}

\section{1. Çalışma alanının genel tanımı}

Diyarbakır ilinin Ergani ilçesi ile Siirt ilinin Kurtalan ilçeleri arasında yer alan çalışma alanı $\left(39^{\circ}\right.$ $45^{\prime} 7^{\prime \prime}$ - $41^{\circ} 30^{\prime} 53^{\prime \prime}$ doğu ve $37^{\circ} 58^{\prime} 41^{\prime \prime}$ - $38^{\circ} 15^{\prime} 14^{\prime \prime}$ kuzey), farklı yoğunluklarda tarımsal üretimin yapıldığ $14.341 \mathrm{~km}^{2}$ 'lik bir bölgeyi kapsamaktadır (Şekil 1). Çalışma alanının kuzey bölümü, KD-GB doğrultusunda uzanmış Güneydoğu Torosların eteklerinden oluşmuştur. Orta Pliyosen dönemindeki tektonik hareketler dağ eteklerinde yer alan düzlüklerin oluşumunu kesintiye uğratmış ve dağlar yükselmeye başlamıştır. Havza çanağ1 çökelmeler neticesinde daha da derinleşmiş ve çökmeler sonucunda havza tabanında "V" biçiminde vadiler oluşmaya başlamıştır (Karadoğan ve ark., 2008). Çalışma alanı toprakları esas olarak bazaltik ve sedimenter ana materyaller üzerinde oluşmuştur. Diyarbakır il merkezinin güneyi ve batısı Karacadağ'dan gelen bazalt özellikli ana materyal üzerinde diğer bölümlerin tamamı ise Şelmo formasyonu üzerinde oluşmuştur. Şelmo formasyonu sedimenter özellikte olup; genellikle killi, siltli, kum taşı, çakıl taşı ve marn gibi materyallerden oluşmuştur (Çelik, 2015).

Çalışma alanında yazları sıcak ve kurak, kışları ise soğuk ve yağışlı olan Güneydoğu Anadolu Bölgesi'nin karasal iklimi hâkimdir. Diyarbakır illinde uzun yıllar (1984-2014) ortalama yıllık yağış miktar1 472 mm, Batman ilinde $470 \mathrm{~mm}$ ve Siirt ilinde ise $685 \mathrm{~mm}$ 'dir. Y1llik ortalama sicaklık ise Diyarbakır ilinde $15.8^{\circ} \mathrm{C}$, Batman ilinde $16.4^{\circ} \mathrm{C}$ ve Siirt ilinde ise $16^{\circ} \mathrm{C}$ 'dir.

Sulama olanağının bulunmadığı arazilerde kuru tarım ile başta buğday olmak üzere, arpa ve mercimek yetiştirilirken; sulama olanağının bulunduğu yerlerde misır ve pamuk gibi tarla bitkileri yetiştiriciliği yapılmaktadır. Bununla birlikte, bağ, erik, fistık ve elma gibi meyve ağaçları; karpuz, fasulye, domates, salatalık, acur, biber ve patlıcan gibi sebze bitkileri yetiştiriciliği de yapılmaktadir.

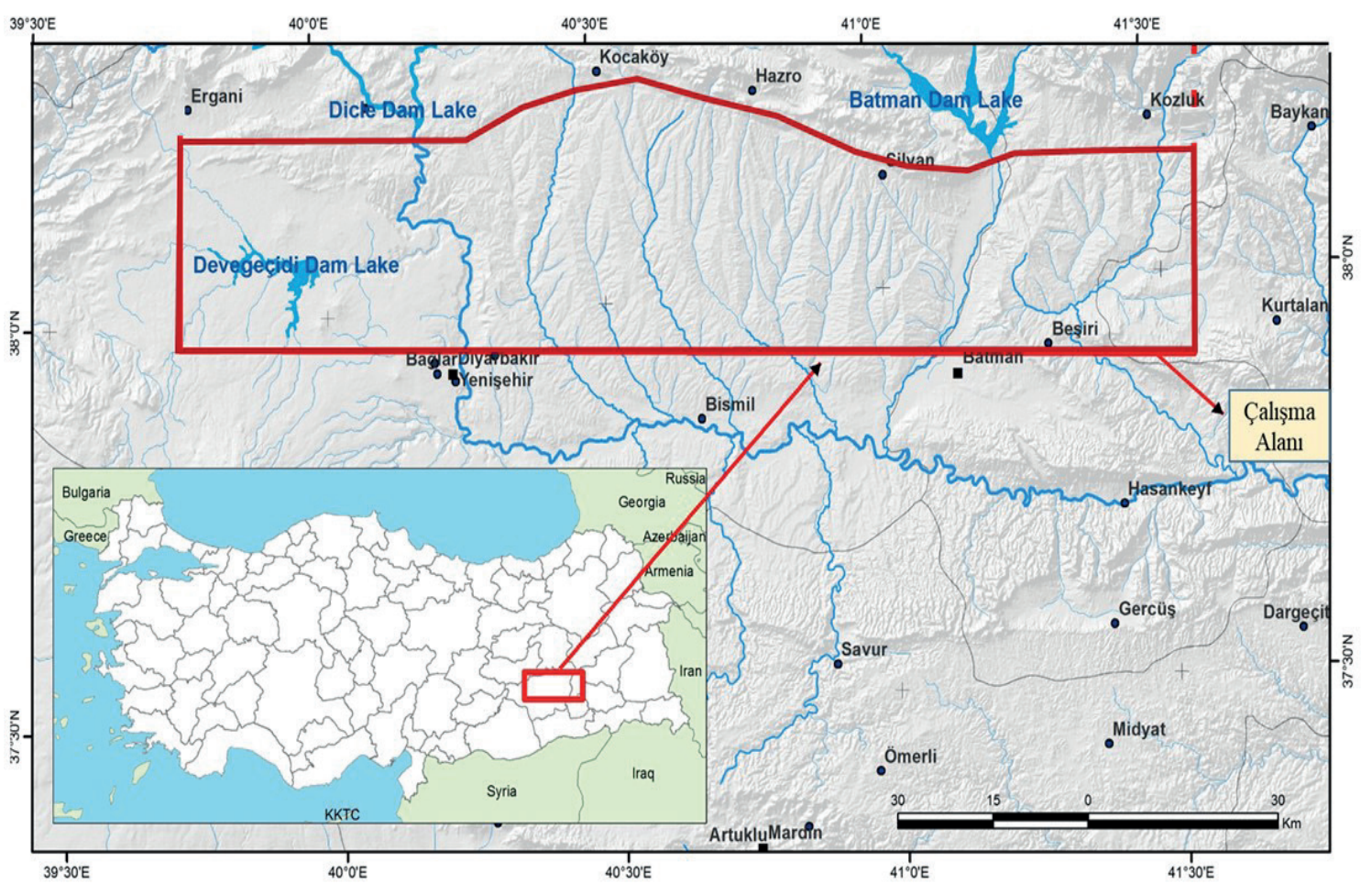

Şekil 1. Çalışma alanının konumu 


\subsection{Toprak örneklemesi}

Toplam $4.341 \mathrm{~km}^{2}$ 'lik genişliğe sahip olan çalışma alanı $5 \mathrm{~km}$ x $5 \mathrm{~km}$ 'lik gridlere ayrılmış; toprak örneklemeleri, her bir gridin yaklaşık olarak köşe noktasından toplam 175 noktada ve $0-20 \mathrm{~cm}$ derinlikte yapılmıştır. Toprak özelliklerinin 5 km'den kısa mesafelerdeki değişimlerinin daha doğru tahmin edilebilmesi amacıyla ardışı iki gridin köşe noktaları arasında $250 \mathrm{~m}, 750 \mathrm{~m}$, ve $1750 \mathrm{~m}$ mesafelerde çalışma alanının farklı yerlerine 11 adet ara örnekleme hatt1 yerleştirilmiştir. Her ara hattan 3 ara noktadan toplam 33 ilave örnek alınmış ve toplam örnek sayısı 208 olmuştur (Şekil 2). Toprak örneklemesinin yapıldı̆̆ 1 dönemde; 85 noktada buğday, 10 noktada arpa, 41 noktada mercimek, 18 noktada misır, 5 noktada nohut, 5 noktada pamuk, 3 noktada karpuz, 2 noktada fiğ ve 11 noktada meyve (asma, fıstık, erik, elma) yetiştiriciliği yapıldığ belirlenmiştir. Toprak örneklerinin alındığ1 28 nokta ise, mera alanlarından oluşmaktadır.

\subsection{Toprak analiz yöntemleri}

Bozulmuş toprak örnekleri oda sıcaklığında kurutulmuş ve laboratuvar analizleri için $2 \mathrm{~mm}$ 'lik elekten geçirilmiş ve analizlere hazır hale getirilmiştir. Çalışmada, parçacık büyüklük dağılımı, hidrometre yöntemine göre (Gee ve Bauder, 1986); elektriksel iletkenlik (EC) ve toprak reaksiyonu $(\mathrm{pH})$, saturasyon çamuru yöntemine göre (Rhoades ve ark., 1999); organik madde (OM), değiştirilmiş Walkey-Black metoduna göre (Nelson ve Sommers, 1982); toprakların kireç $\left(\mathrm{CaCO}_{3}\right)$ içeriği, Scheibler kalsimetresi yöntemine göre (Allison ve Moodie, 1965); alınabilir fosfor (P) konsantrasyonu, sodyum bikarbonat $\left(\mathrm{NaHCO}_{3}\right)$ ekstraksiyon (0.5 $\left.\mathrm{M} \mathrm{NaHCO}_{3}, \mathrm{pH}=8.5\right)$ yöntemine göre (Olsen ve Sommer, 1982) belirlenmiştir. Toprakların alınabilir potasyum $(\mathrm{K})$ içeriği ise, amonyum asetat $\left(1 \mathrm{~N} \mathrm{CH}_{3} \mathrm{COONH}_{4}, \mathrm{pH}=7.0\right)$ ile ektrakte edilmiş örnekten alınan süzükteki $\mathrm{K}$ konsantrasyonu (Jackson, 1958) atomik absorbsiyon spektrofotometresinde saptanmıştır.

\section{4. İstatistiksel analizler ve mesafeye bağlı değişkenliğin analizi}

Analizleri yapılan toprak özelliklerinin; en küçük, en yüksek, ortalama, standart sapma, varyasyon katsayısı ve yatıklık değerlerine ait tanımlayıcı istatistikleri SPSS 21.0 paket programı kullanılarak hesaplanmıştır. Toprak özelliklerinin mesafeye bağlı değişkenlikleri analiz edilmeden önce, dağılımların normal olup olmadıkları kontrol edilmiştir. Çalışılan özelliklerden kil ve kum normal dağılım göstermiştir. Diğer toprak özelliklerinden silt, $\mathrm{OM}, \mathrm{CaCO}_{3}, \mathrm{pH}, \mathrm{EC}, \mathrm{K}$ ve $\mathrm{P}$ verilerine logaritmik dönüşüm uygulanmıştır.

Toprak özelliklerine ait yersel değişkenlikler $\mathrm{GS}^{+} 7.0$ paket programında modellenmiş ve elde edilen model parametrelerinin kullanılarak ArcGIS 10.2 paket programı ile haritalanmıştır.

Semivariogram modellerinin tahmininde Eşitlik 1 kullanılmıştır.

$$
\gamma(h)=\frac{1}{2 N(h)}+\sum_{i=1}^{N(h)}\left[\mathrm{z}\left(\mathrm{x}_{\mathrm{i}}+\mathrm{h}\right)-\mathrm{z}\left(\mathrm{x}_{\mathrm{i}}\right)\right]^{2}(1)
$$

Burada; $h, \mathrm{x}_{\mathrm{i}}$ ile $\mathrm{x}_{\mathrm{i}}+\mathrm{h}$ arasındaki ayırma (range) mesafesini; $\mathrm{N}(\mathrm{h}), \mathrm{h}$ mesafesi ile birbirlerinden ayrılan örnek çifti sayısını; $\mathrm{z}\left(\mathrm{x}_{\mathrm{i}}\right), \mathrm{x}$ noktasında ölçülen özelliğe ait değeri; $\mathrm{z}\left(\mathrm{x}_{\mathrm{i}}+\mathrm{h}\right), \mathrm{x}+\mathrm{h}$ aralık mesafesi bulunan iki noktaya ait özelliğin değerini ifade etmektedir (Isaaks ve Srivastava, 1988).

Araştırma kapsamında incelenen özelliklere ait semivariogramlar oluşturulurken mesafeye bağl1 değişkenliği en iyi tanımlayan modelin seçiminde modele ait $\mathrm{r}^{2}$ ve ölçüm hatalarının göstergesi olan Artık Kareler Toplamı (Residual Sum of Squares, RSS) değerleri dikkate alınmıştır. En iyi modelin seçiminde $\mathrm{r}^{2}$ değerinin 1.0 'a ve RSS değerinin ise sıfir (0)'a yakın olanları tercih edilmiştir (Yang ve ark., 2011). Semivariogram ve çapraz

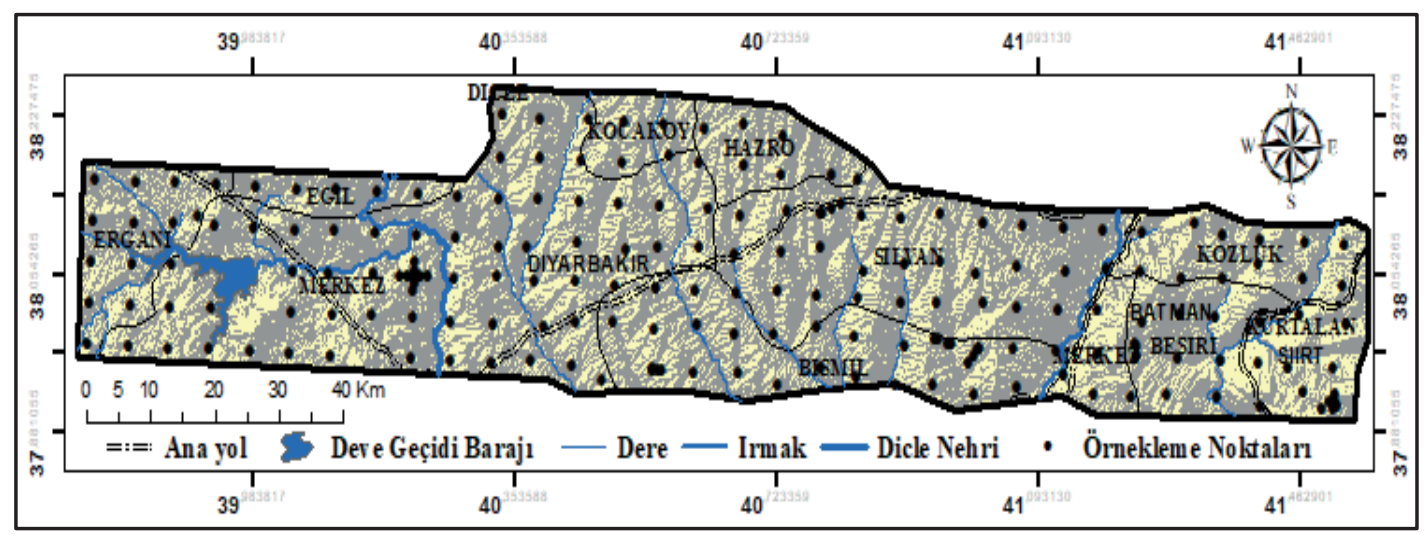

Şekil 2. Çalışma alanında toprak örneklerinin dağılım deseni 
değerlendirme sonucu elde edilen parametreler (nugget, sill, range, aktif lag değeri ve komşu sayısı) kullanılarak ArcGIS programının jeoistatistik modülünde yer alan ordinary kriging yöntemi ile her bir toprak özelliği için yersel değişim haritaları üretilmiştir.

\section{Bulgular ve Tartışma}

\subsection{Tanımlayıcı istatistiksel analizlerin değerlendirilmesi}

Dicle Havzası'nın bir kısım fiziksel ve kimyasal toprak özelliklerine ait tanımlayıcı istatistik parametreleri Tablo 1'de verilmiştir. Yarı kurak bir iklime sahip çalışma alanı toprakları genel olarak düşük organik madde içeriğine (ortalama \% 1.80) sahiptir. Çalışma alanı içerisinde ortalama organik madde içeriği yer yer \% 0.42 gibi çok düşük ve yetersiz görünürken, kimi arazilerde \% 5.14 gibi yüksek düzeylere çıkmaktadır. Kil içeriği ortalama \% 53.1 ve kum içeriği ortalama \% 26.2'dir (Tablo 1). Çalışma alanında kil içeriğinin oldukça yüksek olması Karacadağ kökenli koyu renkli, ince tekstürlü bazalt ana materyalinden kaynaklanmaktadır. $\mathrm{Bu}$ nedenle, Karacadağ eteklerine yakın yerlerde toprakların kil içerikleri \% 77.7'ye kadar çıkmaktadır. Oldukça geniş bir alanı kapsayan çalışma alanında ana materyalin değişimi toprak tekstürünün önemli düzeyde değişmesine neden olduğu gibi, kireç içeriklerinde de çok büyük değişkenliğe neden olmuştur. Bazalt ana materyali üzerinde oluşan arazilerde kireç içeriği \% 1.02 gibi çok düşük değerlere sahip iken; ana materyalin kireççe zengin olduğu şelmo formasyonu üzerinde oluşan bir kısım arazilerde ise \% 36.43 gibi oldukça yüksek bir değer göstermiştir. Yüksek kireç içeriği, özellikle fosfor, demir ve çinko gibi besin elementlerinin bitkilere yarayışlılığını azaltacağından bitkisel üretimin olumsuz etkilenmesine neden olacaktır. Agregatlaşma için önemli bir çimentolayıcı madde olan kireç içeriğinin \% 1.02 gibi çok düşük düzeyde olması da, toprakların bozulmaya karşı direncinin azalmasına neden olabilir. Bu nedenle bu uç değerlerin bulunduğu arazilerde bitkisel üretim yapılırken kireç önemli bir faktör olarak düşünülmeli ve uygun tedbirler alınmalıdır.

Toprak özelliklerinin değişkenliklerinin kıyaslanmasında varyasyon katsayısı (VK) oldukça yaygın olarak kullanılan bir parametredir. Standart sapmanın ortalamaya oranının yüzde olarak ifade edilmesi ile hesaplanan VK, $\leq \% 15$ olduğunda, değişkenlik düşük; \% 15-35 arası olduğunda, orta düzeyde değişken ve $\geq \% 35$ 'ten yüksek olduğunda ise, yüksek düzeyde değişken olarak sınıflandırılmaktadır (Wilding ve ark., 1994). Çalışma alanı içerisinde değişkenliği en düşük olan özellik \% 3.90 ile toprak pH's1 iken, alınabilir P konsantrasyonunun değişkenliğinin oldukça yüksek olduğu $(\% \mathrm{VK}=137.77)$ görülmüştür. Kil ve silt içerikleri orta derecede değişken; kireç, alınabilir K, kum ve organik madde içeriğinin ise yüksek derecede değişkenlik gösterdiği tespit edilmiştir (Tablo 1). Toprak çözeltisindeki hidrojen iyonları konsantrasyonunun logaritmik ifadesini yansitan $\mathrm{pH}$ değerleri diğer toprak özelliklerine kıyasla daha az değişkenlik göstermektedir (Usowicz ve Lipiec, 2017). Calışma alanı topraklarının farklı ana materyaller üzerinde oluşması, rakım (562-914 m) ve arazi eğiminin ( $\%$ 0.32-42.7) yüksek değişkenliğinin yanı sıra, çalışma alanının bulunduğu geniş coğrafyada uygulanan arazi kullanımlarının farklılığı toprak özelliklerinin yüksek düzeyde değişkenlik göstermelerine neden olmuştur.

Toprak özellikleri arasındaki ilişkileri gösteren korelasyon analizine ait sonuçlar Tablo 2'de verilmiștir. Korelasyon analizine göre kil içeriği ile kum, silt, pH ve kireç içerikleri arasında önemli düzeyde negatif bir ilişki $(p<0.01)$ bulunurken; kil içeriği ile EC arasında ise önemli pozitif bir ilişki $(\mathrm{p}<0.01)$ olduğu görülmüştür (Tablo 2). Kil ile kireç içeriği arasındaki negatif ilişki, kil ve kireç içeriklerine ait yersel değişim haritalarında özellikle çalıșma alanının güneybatı kısmında da açıkça görülmektedir. Çalışma alanının güneybatısında bazalt ana materyali üzerinde oluşan toprakların kil içerikleri en yüksek değerleri (\% 77.7) alırken, toprakların kireç içeriği en düşük değerleri (\% 1-2)

Tablo 1. Toprak özelliklerine ait tanımlayıcı istatistik parametreleri

\begin{tabular}{lcccccc}
\hline Toprak özelliği & En düşük & En yüksek & Ortalama & Standart sapma & VK & Çarpıklık \\
\hline Kil, \% & 16.8 & 77.7 & 53.1 & 15.09 & 28.45 & -0.11 \\
Kum, \% & 4.8 & 59.1 & 26.2 & 13.52 & 51.63 & 0.47 \\
Silt, \% & 7.5 & 56.6 & 20.8 & 6.73 & 32.41 & 1.28 \\
Organik madde, \% & 0.42 & 5.14 & 1.80 & 0.68 & 37.68 & 1.21 \\
$\mathrm{CaCO}_{3}, \%$ & 1.02 & 36.43 & 7.68 & 8.02 & 104.40 & 1.68 \\
$\mathrm{pH}$ & 6.61 & 8.55 & 7.69 & 0.30 & 3.90 & -1.27 \\
$\mathrm{EC}, \mathrm{dS} \mathrm{m}^{-1}$ & 0.22 & 1.97 & 0.67 & 0.29 & 42.90 & 1.78 \\
$\mathrm{~K}_{2} \mathrm{O}, \mathrm{kg} \mathrm{da}^{-1}$ & 25.39 & 364.91 & 112.09 & 57.81 & 51.58 & 1.49 \\
$\mathrm{P}_{2} \mathrm{O}, \mathrm{kg} \mathrm{da}^{-1}$ & 1.16 & 78.79 & 6.53 & 8.99 & 137.77 & 4.98 \\
\hline
\end{tabular}

VK: Varyasyon katsayısı (\%) 
Tablo 2. Toprak özellikleri arasındaki korelasyon katsayıları

\begin{tabular}{|c|c|c|c|c|c|c|c|c|}
\hline & Kil & Kum & Silt & $\mathrm{pH}$ & $\mathrm{EC}$ & $\mathrm{K}_{2} \mathrm{O}$ & $\mathrm{P}_{2} \mathrm{O}_{5}$ & $\mathrm{CaCO}_{3}$ \\
\hline Kum & $-0.895^{* *}$ & & & & & & & \\
\hline Silt & $-0.445^{* *}$ & -0.001 & & & & & & \\
\hline $\mathrm{pH}$ & $-0.346^{* *}$ & $0.308^{* *}$ & $0.159^{*}$ & & & & & \\
\hline EC & $0.556^{* *}$ & $-0.464^{* *}$ & $-0.315^{* *}$ & $-0.280^{* *}$ & & & & \\
\hline $\mathrm{K}_{2} \mathrm{O}$ & 0.098 & $-0.154^{*}$ & 0.090 & 0.046 & 0.095 & & & \\
\hline $\mathrm{P}_{2} \mathrm{O}_{5}$ & -0.091 & 0.061 & 0.081 & 0.097 & 0.053 & $0.234^{* *}$ & & \\
\hline $\mathrm{CaCO}_{3}$ & $-0.235^{* *}$ & 0.120 & $0.286^{* *}$ & $0.381^{* *}$ & $-0.245^{* *}$ & 0.076 & $0.170^{*}$ & \\
\hline $\mathrm{OM}$ & 0.067 & -0.117 & 0.084 & -0.080 & 0.025 & $0.144^{*}$ & -0.007 & 0.058 \\
\hline
\end{tabular}

*: $\mathrm{p}<0.05$ düzeyinde önemli, ${ }^{* *}: \mathrm{p}<0.01$ düzeyinde önemli

almıştır. Toprak tekstürü killi olmasına rağmen kireç içeriğinin düşük olmasının temel nedeni, ana materyalin kireç içermiyor olmasıdır. Bunun yanında uygulanan büyük miktardaki sulama sularının yüzey toprağındaki kireci yıkayıp alt katmanlara taşıması da düşük kireç içeriğine neden olduğu düşünülmektedir. Akdeniz Bölgesi'nin kurak bölgelerinde biyojeokimyasal süreçlerin çoğunun bulunduğu yüzey katmanda $(0-20 \mathrm{~cm})$ sulama suyunun kireç konsantrasyonu üzerine önemli düzeyde etki ettiği bildirilmiştir (De Soto ve ark., 2017). Araştırmacılar, çalışmada tarım arazilerinde kullanılan suların üst toprakta bulunan karbonat konsantrasyonunda önemli bir azalmaya neden olduğunu da rapor etmiştir. Yine aynı araştırmacılar, yarı kurak iklim bölgelerinde yağışın yüzey katmandaki kireci yıkayıp profilden uzaklaştırmaya yettiğini de rapor etmişlerdir. Presley ve ark. (2004) da yıllık ortalama yağışın 400 ile $500 \mathrm{~mm}$ arasında değiştiği batı Kansas'da sulama ile birlikte verilen 300 ile $600 \mathrm{~mm}$ suyun tarım arazilerinde 30 y1l sonunda kil yıkanması ve ayrışmayı arttırdığını ve yüzey toprağının $\mathrm{pH}$ ve değişebilir sodyum yüzdesini değiştirdiğini ve toprak oluşum işlemlerini arttırarak doğal genetik işlemleri değiştirdiğini bildirmişlerdir. Bununla birlikte organik karbon ve kireç içeriğinin ise önemli düzeyde değişmediği rapor edilmiştir.

Toprakların EC değerleri ile $\mathrm{pH}$ değeri ve kireç içeriği arasında da önemli düzeyde negatif ilişki $(p<0.01)$ söz konusu iken, $p H$ ile kireç içeriği arasında önemli pozitif bir ilişki $(p<0.01)$ olduğu görülmüştür (Tablo 2). Çalışma alanında kireç içeriğinin düşük olduğu alanlarda $\mathrm{pH}$ değerinin düşük, kireç içeriğinin yüksek olduğu alanlarda ise $\mathrm{pH}$ değerinin yüksek olduğu görülmektedir. $\mathrm{Bu}$ çalışmada elde edilen bulguları destekleyen Suarez (1995) de, kireç içeriği ile pH arasında önemli bir ilişkinin olduğunu ve kirecin yüksek olduğu topraklarda toprak pH'sının yüksek (bazik) olduğunu, toprakta bulunan kirecin kalsit formunda olduğu durumlarda ise pH'nın 7.0 ile 8.5 arasında değişim gösterdiğini rapor etmiştir.

Bitki gelişimindeki önemlerinden dolayı temel besin elementi olarak sınıflandırılan alınabilir K ve
P konsantrasyonları arasında da önemli düzeyde pozitif bir ilişki $(\mathrm{p}<0.01)$ söz konusudur. Ayrıca alınabilir P ile kireç arasında zayıf bir pozitif bir ilişki $(\mathrm{p}<0.05, \mathrm{r}=0.17)$ söz konusudur (Tablo 2). Genellikle kireç taşı, marn ve benzeri ana materyal üzerinde oluşan topraklar ana materyali kireçsiz olan topraklara kıyasla daha yüksek düzeyde $\mathrm{P}$ içeriğine sahiptirler (Frossard ve ark., 2000). Kirecin yüksek olduğu yerlerde $\mathrm{P}$ ile $\mathrm{Ca}$ bileşik oluşturarak çözünürlüğü daha az olan $\mathrm{CaPO}_{4}$ bileşiklerine dönüşmektedir (Lindsay ve ark., 1989). Bununla birlikte, beklentilerin aksine çalışma alanında kireç içeriğinin yüksek olduğu alanlarda P içeriğinin çözünürlüğünün azalmasına bağlı olarak negatif bir ilişki olması beklenirken, zayıf pozitif bir ilişki olduğu görülmektedir. Elde edilen bulgular, çalışma alanında ana materyal ve amenajman uygulamalarının toprak özellikleri üzerinde önemli bir etkiye sahip olduğunu ve toprak özellikleri arasındaki korelasyonun bu faktörlere bağlı olarak değiştiğini göstermektedir.

\subsection{Toprak özelliklerinin mesafeye bağlı değişimlerinin modellenmesi ve haritalanması}

Toprak özellikleri için elde edilen semivariogram modellerine ait parametreler Tablo 3 'te verilmiştir. Toprak özelliklerinden $\mathrm{pH}$ için mesafeye bağlı değişkenliği en iyi tanımlayan model normal (gaussian) model iken diğer özelliklerin tamamı için üssel (exponential) model en iyi model olarak elde edilmiştir (Tablo 3, Şekil 3). Arazide iki nokta arasındaki toprak özelliklerinin yersel değişimlerinin boyutunun ifade edilmesinde uzaysal bağımlılık yaygın olarak kullanılmaktadır. Uzaysal bağımlılık değeri, nugget (Co) semivaryansin toplam semivaryansa $(\mathrm{Co}+\mathrm{C})$ oranının $(\mathrm{Co} / \mathrm{Co}+\mathrm{C})$ yüzde olarak ifadesidir (Wang ve Shao, 2013). Uzaysal bağımlılık değeri $\leq \% 25$ olduğunda toprak özelliğinin kuvvetli derecede, $\% 25$ ile \% 75 arasinda orta derecede ve \% 75 'ten fazla olduğunda ise uzaysal bağımlılığın zayıf derecede olduğu anlaşılmaktadır. Toprak özelliklerinden $\mathrm{pH}(\% 0.06)$, silt içeriği (\% 3.71) ve alınabilir P (\% 12.63) kuvvetli uzaysal bağımlılığa sahip iken, diğer toprak özellikleri orta derecede 
Tablo 3. Toprak özellikleri için elde edilen semivariogram modellerine ait parametreler

\begin{tabular}{lcccccccc}
\hline $\begin{array}{l}\text { Toprak } \\
\text { ozzelliği }\end{array}$ & Model & Nugget $(\mathrm{Co})$ & $\begin{array}{c}\text { Sill } \\
(\mathrm{Co}+\mathrm{C})\end{array}$ & $\begin{array}{c}\text { Uzaysal } \\
\text { bağımlılık }\end{array}$ & $\begin{array}{c}\text { Range } \\
(\mathrm{m})\end{array}$ & $\mathrm{r}^{2}$ & RSS & $\begin{array}{c}\text { Dağılım } \\
\text { ön işlemi }\end{array}$ \\
\hline Kil & Üssel & 60.6 & 157.5 & 38.48 & 29520 & 0.97 & 203 & Normal \\
Kum & Üssel & 81 & 162 & 50.00 & 100800 & 0.93 & 130 & Normal \\
$\mathrm{Silt}$ & Üssel & 0.0034 & 0.0916 & 3.71 & 7260 & 0.73 & $8.86 \mathrm{E}-05$ & Log. Dönüşüm \\
pH & Üssel & 0.000001 & 0.00156 & 0.06 & 4740 & 0.98 & $7.70 \mathrm{E}-09$ & Log. Dönüşüm \\
$\mathrm{EC}$ & Normal & 0.0679 & 0.2688 & 25.26 & 135400 & 0.96 & $1.32 \mathrm{E}-04$ & Log. Dönüşüm \\
$\mathrm{CaCO}{ }_{3}$ & Üssel & 0.435 & 1.054 & 41.27 & 26400 & 0.96 & 0.0109 & Log. Dönüşüm \\
$\mathrm{OM}$ & Üssel & 0.0784 & 0.1578 & 49.68 & 35010 & 0.94 & $2.31 \mathrm{E}-04$ & Log. Dönüşüm \\
$\mathrm{K}_{2} \mathrm{O}$ & Üssel & 0.1486 & 0.2982 & 49.83 & 36210 & 0.91 & $2.08 \mathrm{E}-03$ & Log. Dönüşüm \\
$\mathrm{P}_{2} \mathrm{O}_{5}$ & Üssel & 0.107 & 0.847 & 12.63 & 5040 & 0.92 & $1.03 \mathrm{E}-02$ & Log. Dönüşüm \\
\hline
\end{tabular}

RSS: Artık Kareler Toplamı (Residual Sum of Squares)
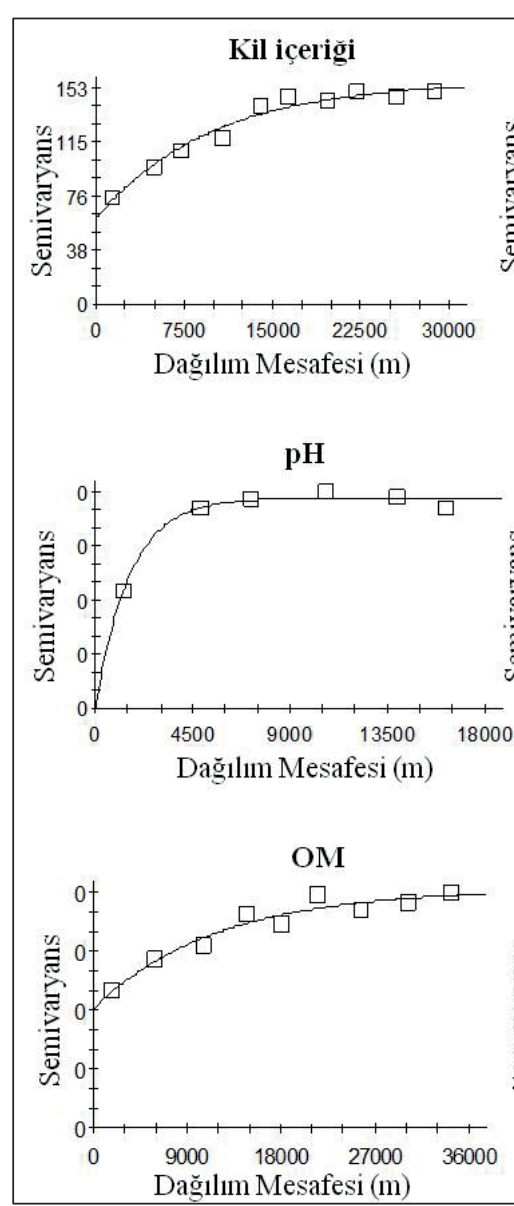
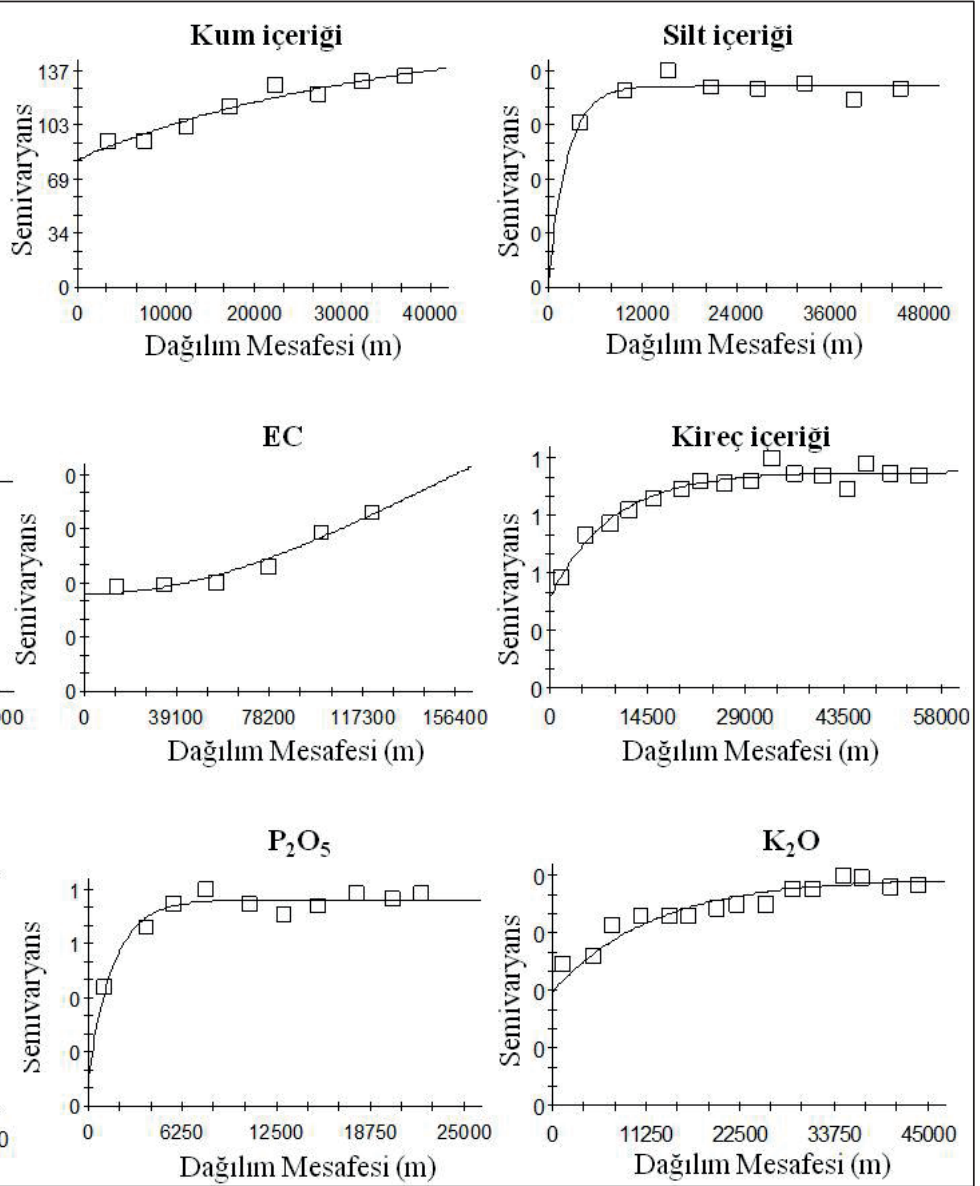
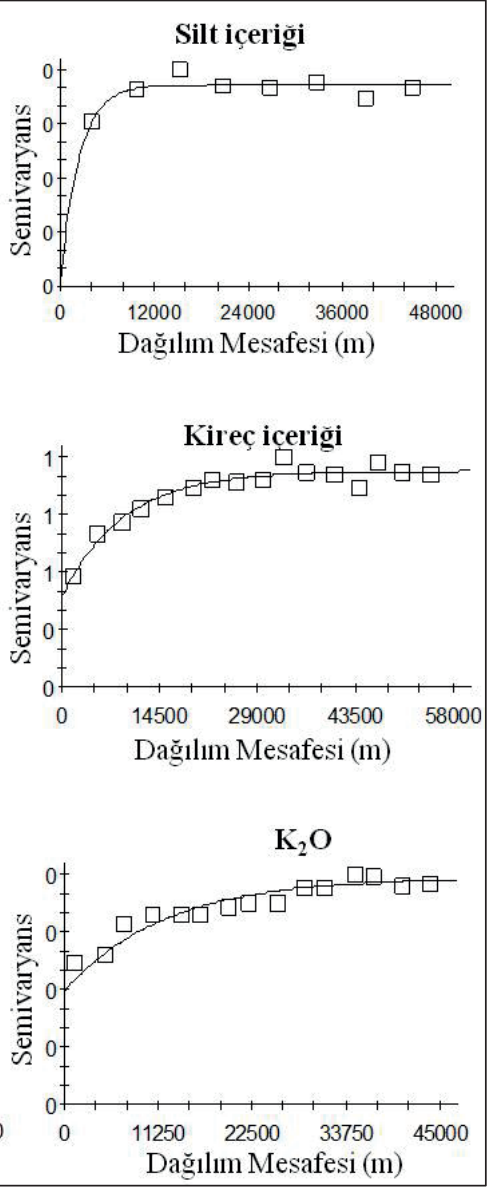

Şekil 3. Toprak özelliklerine ait semivariogram modelleri

uzaysal bağımlılık göstermişlerdir (Tablo 3). Örnekler arası uzaysal bağımlılığın güçlü olması kısa mesafelerde örnekler arası benzerliğin ortadan kalkmadığını ve uzun mesafelerde dahi devam ettiğini göstermektedir.

Semivariogram modelinden elde edilen range değerleri iki örnekleme veya tahmin noktası arasındaki benzerliğin devam ettiği mesafeyi vermektedir. Jeoistatistiğin temelinde toprak örneği alınan iki nokta arasındaki benzerliğin mesafeye bağlı olarak azaldığı ve belirli bir mesafeden sonra benzerliğin tamamen yok olduğu varsayımı esastır (Deutsch ve Journel, 1992). Elde edilen bulgulara göre en yüksek range değeri $135.4 \mathrm{~km}$ ile $\mathrm{EC}$ ve en küçük range değeri ise $4.74 \mathrm{~km}$ ile toprak $\mathrm{pH}$ 'sına ait olduğu görülmektedir. Diğer toprak özelliklerinden kum, K, OM, kil, kireç, silt ve P'a ait range değerleri ise sirası ile 100.8, 36.2, 35.0, $29.5,26.4,7.3$ ve $5.0 \mathrm{~km}$ 'dir. Yapılan çalışmalarda range değerinin çalışma yapılan alanın büyüklüğüne bağl1 olarak büyük değişkenlik gösterdiği anlaşılmaktadır. Dey ve ark. (2017), 
$4.949 \mathrm{~km}^{2}$ 'lik bir alanda yaptıkları çalışmada range değerini $\mathrm{pH}$, organik madde ve potasyum için 95.8 $\mathrm{km}$, EC için ise $92.7 \mathrm{~km}$ ve fosfor için $24.8 \mathrm{~km}$ olarak rapor etmiştir. Daha dar bir alanda $\left(215 \mathrm{~km}^{2}\right)$ çalışan Vasu ve ark. (2017) ise organik madde için range değerini $1.54 \mathrm{~km}, \mathrm{~K}$ için $1.29 \mathrm{~km}, \mathrm{pH}$ için $1.27 \mathrm{~km}$ ve $\mathrm{P}$ için $1.19 \mathrm{~km}$ olarak rapor etmiştir. Bugüne kadar yapılan çalışmaların birçoğunda diğer toprak özelliklerine kıyasla P değerinin daha kısa aralıklarla değişim gösterdiği ve bu nedenle de daha düşük range değerine sahip olduğu görülmüştür (Roger ve ark., 2014; Vasu ve ark., 2017). Amenajman yöntemleri ve toprak tekstürü, topraktaki alınabilir P konsantrasyonunun mesafeye bağlı değişimi üzerinde önemli bir etkiye sahiptir ve çok kısa mesafelerde önemli bir değişkenlik göstermektedir (O’Halloran ve ark., 1985). Roger ve ark. (2014) da; $1670.7 \mathrm{~km}^{2}$ 'lik farklı toprak tipi ve arazi kullanımlarının yer aldığı çalışma alanlarında ana materyalin, arazi kullanımlarının ve arazi özelliklerinin fosfor içeriğinin dağılımında önemli bir rol oynadığını bildirmişlerdir. Çalışma alanında görülen farklı ana materyal ve toprak tekstürü yanı sıra toprak analizine bağlı kalmadan kimi arazi sahiplerinin her yıl aynı dozda fosforlu gübre kullanması ve bazı arazi sahiplerinin ise herhangi bir fosforlu gübre kullanmaması, alanda fosfor içeriğinin çok kısa mesafelerde yersel değişim göstermesine neden olmuştur.

Bugüne kadar yapılan çalışmaların birçoğunda diğer toprak özelliklerine kıyasla EC değerinin daha kısa aralıklarla değişim gösterdiği ve bu nedenle de daha düşük range değerine sahip olduğu görülmektedir. Emadi ve ark. (2008), EC'nin kısa aralıklarda (1.6-2.1 km) büyük değişim gösterdiğini bildirirken, $\mathrm{pH}(1.8-7.34 \mathrm{~km})$ ve kil içeriğinin (1.6-17.1 km) daha yüksek bir mesafede değişim gösterdiğini tespit emiştir. Araştırmacılar EC'nin arazide çok yüksek bir değişkenlik göstermesinin nedeninin, alanda yapılan farklı uygulamalardan ve drenaj koşullarındaki heterojenlikten kaynaklandığını rapor etmiştir. Toprak tekstürünün de EC'nin arazide gösterdiği yersel değişim deseni üzerine önemli bir etkiye sahip olduğu da belirtilmiştir (Pedrera-Parrilla ve ark., 2016). Çalışma alanında farklı amenajman uygulamaları olmasına ve tekstürün kısa mesafelerde yersel değişim göstermesine rağmen EC çok yüksek bir mesafede benzerlik göstermiştir. Çalışma alanında EC için range değerinin kısa mesafelerde elde edilmesinin, alanın benzer iklimsel özelliklere sahip olması ve ana materyallerin tuz minerallerince zengin olmamasından kaynaklandığ1 düşünülmektedir. Tüm alandaki toprak örneklerinin EC değerlerinin de 0.22 ile $1.97 \mathrm{dS} \mathrm{m}^{-1}$ gibi oldukça dar bir aralıkta değişim göstermesi de yersel değişim mesafesinin yüksek olmasını açıklamaktadır (Tablo 3).

Semivariogram modelleri oluşturulduktan sonra ordinary kriging yöntemi kullanılarak toprak özelliklerine ait yersel değişim haritaları oluşturulmuştur (Şekil 4 ve 5). Toprağın 2 mm'den küçük olan mineral parçacıklarının oranı şeklinde tanımlanan tekstür, toprağın birçok fiziksel, kimyasal ve biyolojik özelliği üzerine etki emektedir (Arshad ve Coen 1992; Dexter, 2004). Toprak tekstür bileşenlerine ait yersel değişim haritaları incelendiğinde çalışma alanının güney batı kısmında yer alan araziler yüksek kil içeriğine sahip iken Batman ilinin içinden geçen ve Dicle Nehri'nin yan kolu olan İlluh (Batman Deresi) Deresi çevresinde kum içeriği yüksek araziler olduğu görülmektedir. Genetik bir özellik olduğundan dolayı tekstür bileşenlerinin daha uzun mesafelerde değişim göstermesi beklenirken, kısa mesafelerde yüksek yersel değişim göstermesi ana materyalin kısa mesafelerde değişmesinden kaynaklanmaktadır. Çalışma alanında yer alan çok sayıdaki derenin, araziyi parçalayarak getirdikleri sedimentleri depolamış olmaları da tekstür bileşenlerinin kı mesafelerde değişkenlik göstermelerine neden olmuştur (Şekil 4). Iqbal ve ark. (2005)'na göre dereler ve akarsular tarafından taşınan alüvyonlar üzerinde oluşan tarım arazilerinde toprak tekstür bileşenleri heterojen bir yapı gösterip, çok kısa mesafelerde değişim gösterebilmektedir. Arazide toprak tekstüründeki yersel değişim toprağın besin depolama ve besin elementlerinin yarayışlılı̆̆ına, su tutma kapasitesine, suyun yarayışlılığına, suyun hareketine ve potansiyel olarak verimliliğine önemli düzeyde etki etmektedir. Toprak tekstürünün bu yersel değişkenliğinin, hem bitki türlerinin seçiminde hem de sulama sistemlerinin dizayn edilmesi ve sulama zamanlarının belirlenmesinde dikkate alınması gerekmektedir.

Organik madde, $\mathrm{pH}, \mathrm{EC}$, kireç içeriği, alınabilir $K$ ve $P$ için oluşturulan mesafeye bağlı değişkenlikleri Şekil 5'te verilen haritalarda gösterilmektedir. Toprağın birçok fiziksel (strüktür oluşumu, toprağın su tutma kapasitesi ve havalanması, toprak sicaklı̆̆1) (Dexter ve ark., 2008) ve kimyasal (katyon değişim kapasitesi, pH'nın düzenlenmesi, besin elementi alımının artması) (Tan ve Dowling, 1984) özelliği üzerine toprak organik maddesinin direk ve dolaylı etkisinin olduğu bildirilmektedir. $\mathrm{Bu}$ önemli etkisinden dolayı çalışma alanında organik maddenin \% 0.42 gibi çok düşük olduğu alanlarda toprak verimliliğinin düşük olması, bozulmaya karşı dayanımın yetersiz ve erozyon riskinin ise yüksek olması muhtemeldir. Mesafeye bağlı 


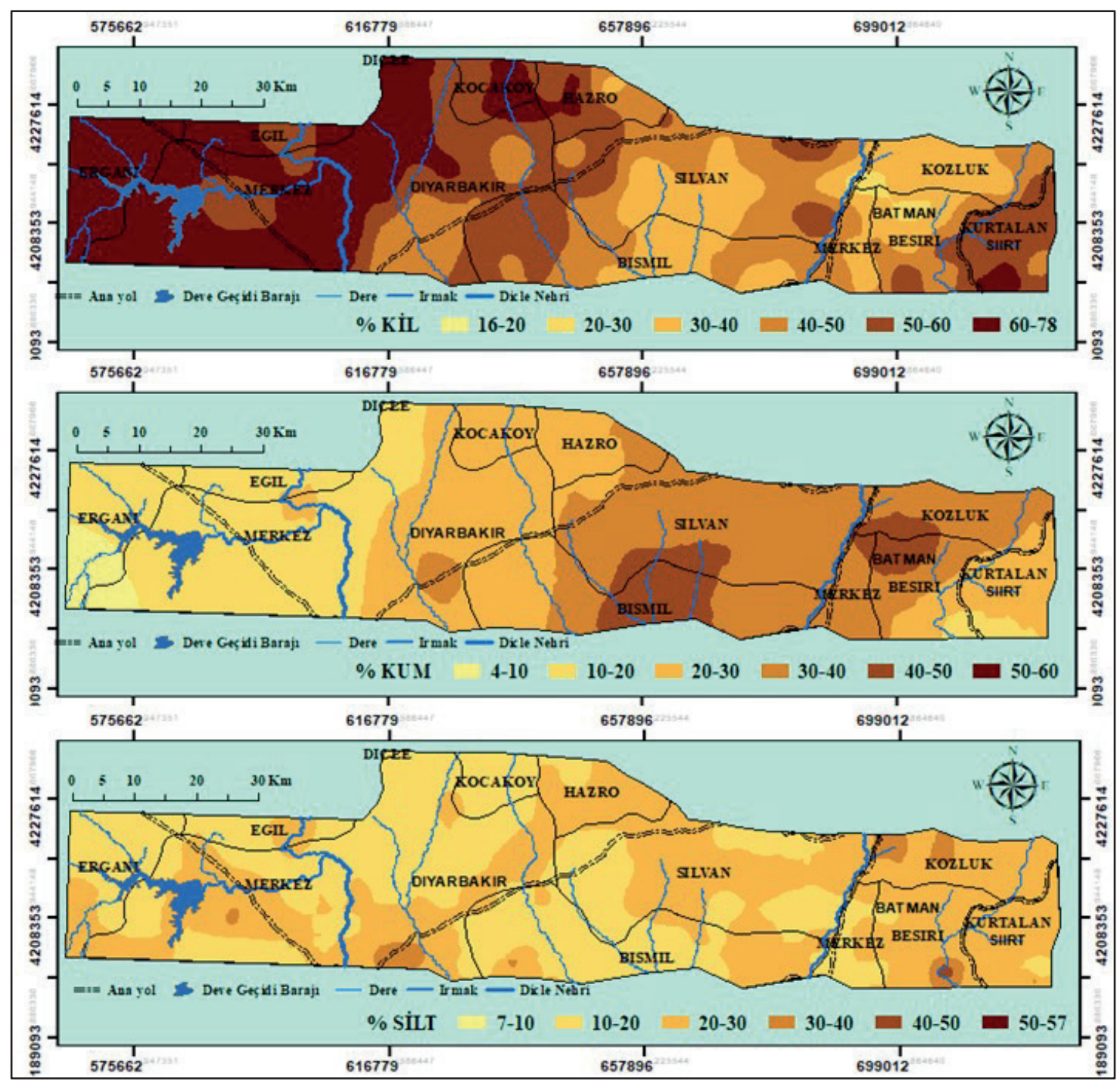

Şekil 4. Tekstür bileşenlerine (kil, kum ve silt) ait yersel değişim haritaları

dağılımın gösterildiği haritanın kullanımı ile çalışma alanının hangi bölgelerinde organik bakımından tedbir alınması gerektiği rahatlıkla anlaşılabilmektedir.

Bazalt ana materyali üzerinde oluşan güney-batı toprakları, yüksek kil içeriğine sahip olmasının yanı sıra; düşük kireç (\% 1-2) ve $\mathrm{P}$ içeriği (2.5-7.5 kg $\left.\mathrm{P}_{2} \mathrm{O}_{5} \mathrm{da}^{-1}\right)$, nispeten yüksek EC (0.8-2.0 $\left.\mathrm{dS} \mathrm{m} \mathrm{m}^{-1}\right)$ değeri, nötr ve nötre yakın $\mathrm{pH}$ (6.6-7.2) değeri ve yüksek K konsantrasyonuna (88-365 $\mathrm{kg} \mathrm{K}_{2} \mathrm{O} \mathrm{da}^{-1}$ ) sahiptir (Şekil 5). Uzun (2013) yaptığı çalışmada Karacadağ bazaltları üzerinde oluşan toprakların kireç içeriğinin \% 3.6-77.0 arasında değiştiğini ve derinlikle beraber kireç içeriğinin arttığını rapor etmiştir. Çalışma alanında kireç içeriğinin yüksek olduğu doğu bölümündeki topraklar çoğunlukla marn özellikli Şelmo formasyonu üzerinde oluşmuştur (Çelik, 2015). Bu alanda kireç içeriği \% 36.4'e kadar çıkmıştır.
Bitki kök gelişimi başta olmak üzere bitkinin birçok fonksiyonu üzerine olan etkisinden dolayı fosfor bitki gelişimi için mutlak gerekli olan besin elementlerinden biri olarak kabul edilmektedir. $\mathrm{Bu}$ nedenle tarımsal üretim yapilan alanlarda toprakların alınabilir P konsantrasyonlarının yersel değişimi dikkate alınarak noksanlık ve fazlalık olan alanların belirlenmesi ve gerekli tedbirlerin alınması gerekmektedir. Alınabilir P için hazırlanan yersel değişim haritası incelendiğinde, çalışma alanında P içeriği oldukça yüksek bir yersel değişim göstermiştir (Şekil 5). Bunun temel nedenlerinden biri; yoğun tarımsal üretim yapılan alanlarda her yıl toprak analizi yapılmadan çiftçinin gelir durumuna göre P içerikli gübreler kullanması, diğeri ise ana materyalin farklı olmasından dolayı toprak tekstürü ve kireç içeriğinin farklı olmasıdır. Çalışma alanında alınabilir P konsantrasyonu 1.15 ile 78.79 $\mathrm{kg} \mathrm{P}_{2} \mathrm{O}_{5} \mathrm{da}^{-1}$ arasında değişim göstermekte olup ortalama $6.53 \mathrm{~kg} \mathrm{da}^{-1}$ 'dır. Çalıșma alanının önemli 


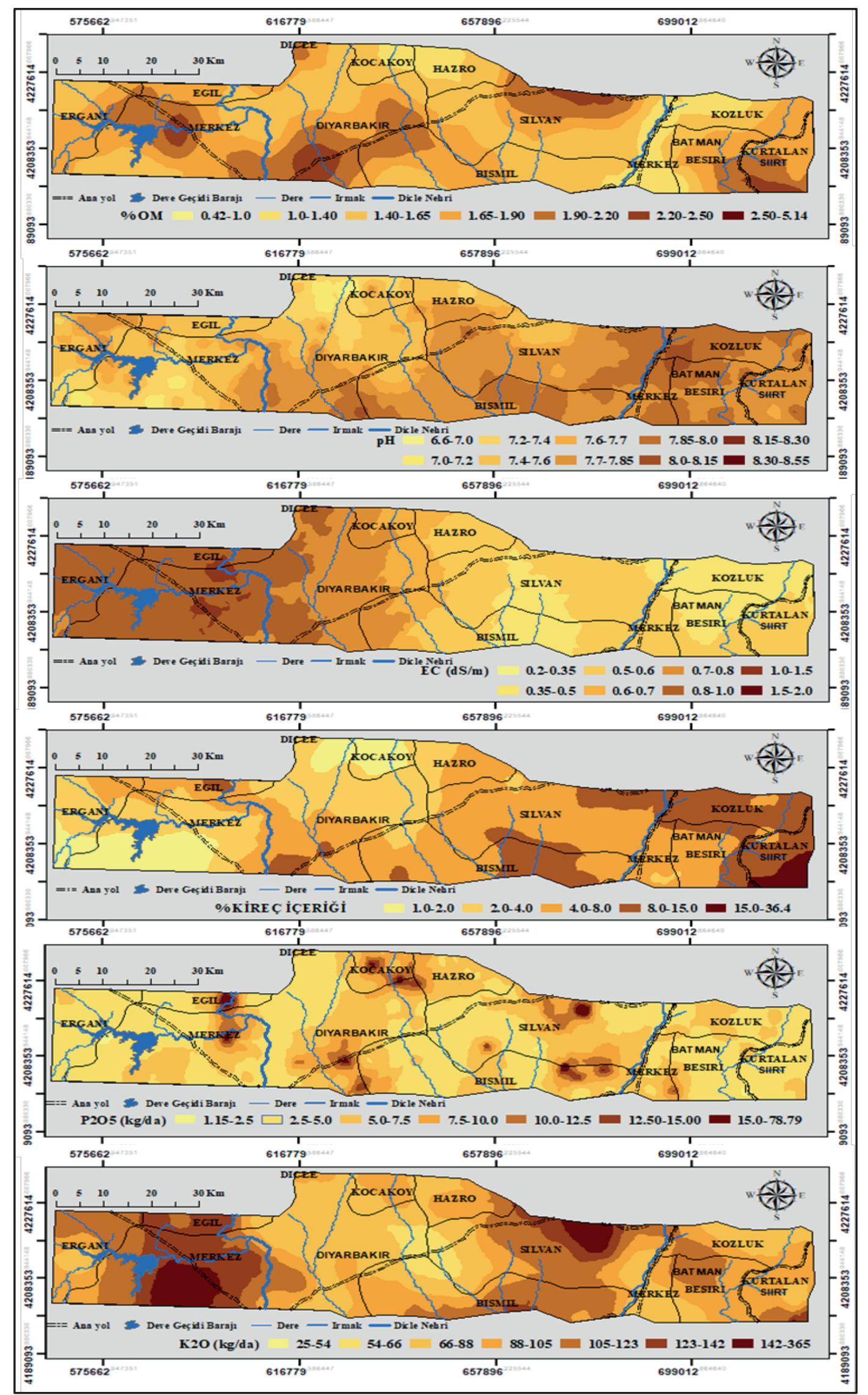

Şekil 5. Organik madde, EC, pH, kireç, fosfor ve potasyum konsantrasyonlarına ait yersel değişim haritaları 
bir kısmında yer alan toprakların alınabilir $\mathrm{P}$ konsantrasyonu Horneck ve ark. (2011)'nın yaptıkları sınıflamaya göre kritik değer olan 10 ppm $\left(4.58 \mathrm{~kg} \mathrm{da}^{-1}\right)$ 'ın altındadır.

Toprak reaksiyonu $(\mathrm{pH})$, bitki besin elementlerinin toprakta yarayışlılı̆̆ üzerine önemli bir etkiye sahiptir (Truog, 1947). Bu nedenle bitkisel üretimde bitki çeşidi seçiminde ve gübre uygulamalarında göz önünde bulundurulması gereken bir özelliktir. Bitki besin elementlerinin en yarayışlı olduğu pH aralığı 6.5-7.5 arasında olduğu bildirilmiştir (Lindsay ve ark., 1989). Çalışma alanda $\mathrm{pH}, 6.6-8.55$ arasında değişmekte olup ortalama 7.69'dur (Tablo 1, Şekil 5). Çalışma alanının bat1, güneybatı ve kuzeybatı kısmında $\mathrm{pH}$ 6.6-7.4 arasında değişmekte olup bitkisel üretim açısından herhangi bir sorun teşkil etmemektedir. Ancak alanın, güney, güneydoğu ve kuzeydoğusunda $\quad \mathrm{pH} \quad$ 7.4-8.55 arasında değişmektedir. Toprak pH'sının 7.5'in üzerinde olduğu yerlerde bitkilerin besin elementi kullanmasında sorunlar yaşanabileceği hatırda tutulmalıdır. Toprak pH'sının yüksek olmasının nedeni ana materyalin kireççe zengin olmasının yanında, kullanılan gübre çeşitlerinin de etkili olduğu düşünülmektedir. Toprak analizine dayalı olmayan gübreleme uygulamaları ve özellikle kalsiyum amonyum nitrat gübresinin bölgede fazla kullanılması toprak pH'sının zamanla yükselmesine neden olabilmektedir.

\section{Sonuçlar}

Dicle Havzası'nda ana materyalin ve tarımsal uygulamaların (gübreleme, sulama, toprak işleme vb) toprak özelliklerine ait yersel değişime önemli düzeyde etki ettiği ve özelliklede toprak pH'sı ve alınabilir fosfor içeriğinin çok kısa mesafelerde yersel değişim gösterdiği tespit edilmiştir. Çalışma alanının doğu, güneydoğu ve kuzeydoğu kısmında toprak pH'sının bitkisel üretim için sorun teşkil edebilecek sınır değerlere ulaştığı belirlenmiştir. Elde edilen sonuçlar toprak özelliklerine ait yersel değişim haritalarının, havza bazında topraklar ile ilgili genel bir bilgi edinilebilmesi açısından son derece yararlı olduğunu göstermektedir. Besin elementlerinin düşük ve yüksek olduğu lokasyonların belirlenmesi tarımsal üretimde planlama yapan idarecilerin karar almalarını kolaylaştırabilecektir. Mesafeye bağlı değişkenliğin gösterildiği haritalar kullanıcıların amacına bağlı olarak farklı ölçeklerde basılabilir. Bu haritaların kullanılması ile bitki türlerinin seçimi, sulama sistemlerinin dizayn edilmesi, sulama zamanlarının ve gübre miktarlarının belirlenmesinde arazi kullanıcılarına kolaylık sağlaması yanı sıra işgücü, zaman ve maliyette de tasarruf sağlayacaktır.

\section{Teşekkür}

Bu çalışma, 2140374 no’lu TÜBİTAK projesi kapsamında desteklenmiştir.

\section{Kaynaklar}

Allison, L.E., Moodie, C.D., 1965. Carbonate. In: C.A. Black et al. (Ed.) Methods of soil Analaysis, Part 2. Agronomy Series, American Society of Agronomy U.S.A., p: 1379-1400.

Arshad, M.A., Coen, G.M., 1992. Characterization of soil quality: Physical and chemical criteria. American Journal of Alternative Agriculture, 7(1-2): 25-31.

Barik, K., Aksakal, E.L., Islam, K.R., Sari, S., Angin, I., 2014. Spatial variability in soil compaction properties associated with field traffic operations. Catena, 120: 122-133.

Budak, M., 2012. Tuzlu alkali toprakların oluşumu, sınıflandırılması ve klasik toprak etüd ve jeoistatistik yöntemlerle haritalanmasi. Doktora tezi, Gaziosmanpaşa Üniversitesi Fen Bilimleri Enstitüsü, Tokat.

Cambardella, C.A., Moorman, T.B., Parkin, T.B., Karlen, D.L., Novak, J.M., Turco, R.F., Konopka, A.E., 1994. Field-scale variability of soil properties in central Iowa soils. Soil Science Society of America Journal, 58(5): 1501-1511.

Cao, S., Lu, A., Wang, J., Huo, L., 2017. Modeling and mapping of cadmium in soils based on qualitative and quantitative auxiliary variables in a cadmium contaminated area. Science of the Total Environment, 580: 430-439.

Celik, R., 2015. Temporal changes in the groundwater level in the Upper Tigris Basin, Turkey, determined by a GIS technique. Journal of African Earth Sciences, 107: 134-143.

De Soto, I.S., Virto, I., Barré, P., Fernández-Ugalde, O., Antón, R., Martínez, I., Chaduteau, C., Enrique A., Bescansa, P., 2017. A model for field-based evidences of the impact of irrigation on carbonates in the tilled layer of semi-arid Mediterranean soils. Geoderma, 297: 48-60.

Denton, O.A., Aduramigba-Modupe, V.O., Ojo, A.O., Adeoyolanu, O.D., Are, K.S., Adelana, A.O., Oke, A.O., 2017. Assessment of spatial variability and mapping of soil properties for sustainable agricultural production using geographic information system techniques (GIS). Cogent Food and Agriculture, 3(1): $1-12$.

Deutsch, V., Journel, A.G., 1992. Geostatistical Software Library and User's Guide. Oxford University Press, New York.

Dexter, A.R., 2004. Soil physical quality: Part I. Theory, effects of soil texture, density, and organic matter, and effects on root growth. Geoderma, 120(3): 201214.

Dexter, A.R., Richard, G., Arrouays, D., Czyz, E.A., Jolivet, C., Duval, O., 2008. Complexed organic matter controls soil physical properties. Geoderm, 144(3-4): 620-627. 
Dey, P., Karwariya, S., Bhogal, N.S., 2017. Spatial variability analysis of soil properties using geospatial technique in katni district of Madhya Pradesh, India. International Journal of Plant \& Soil Science, 17(3): $1-13$.

Emadi, M., Baghernejad, M., Emadi, M., Maftoun, M., 2008. Assessment of some soil properties by spatial variability in saline and sodic affected soils in Arsanjan Plain, Fars Province, Southern Iran. Pakistan Journal of Biological Sciences, 11(2): 238243.

Erdem, H., Budak, M., Acir, N., Gökmen, F., 2012. Micronutrient variability in a lacustrine environment of calcic haplosalids. Fresenius Environmental Bulletin, 21(3): 553-562.

Frossard, E., Condron, L.M., Oberson, A., Sinaj, S., Fardean, J.C., 2000. Procesess governing phosphorus availability in temperate soils. Journal of Environmental Quality, 29(1): 15-23.

Gee, G.W., Bauder, J.W., 1986. Particle-size Analysis. Methods of Soil Analysis: Part 1-Physical and Mineralogical Methods, (Methodsofsoilan1). Soil Science Society of America, American Society of Agronomy, Book Series 5.1, South Segoe Road, Madison, USA, p: 383-411.

Glendell, M., Granger, S.J., Bol, R., Brazier, R.E., 2014. Quantifying the spatial variability of soil physical and chemical properties in relation to mitigation of diffuse water pollution. Geoderma, 214: 25-41.

Goovaerts, P., 1998. Geostatistical tools for characterizing the spatial variability of microbiological and physico-chemical soil properties. Biology and Fertility of Soils, 27(4): 315334.

Günal, H., Acir, N., Budak, M., 2012. Heavy metal variability of a native saline pasture in arid regions of Central Anatolia. Carpathian Journal of Earth and Environmental Sciences, 7(2): 183-193.

Horneck, D.A., Sullivan, D.M., Owen, J.S., Hart, J.M., 2011. Soil Test Interpretation Guide. [Corvallis, Or.]: Oregon State University, Extension Service.

Iqbal, J., Thomasson, J.A., Jenkins, J.N., Owens, P.R., Whisler, F.D., 2005. Spatial variability analysis of soil physical properties of alluvial soils. Soil Science Society of America Journal, 69(4): 1338-1350.

Isaaks, E.H., Srivastava, R.M., 1988. Spatial continuity measures for probabilistic and deterministic geostatistics. Mathematical Geology, 20(4): 313-341.

Jakson, M.L., 1958. Soil Chemical Analysis. PrenticeHall Inc., Englowed Cliffts, New Jersey U.S.A.

Kalivas, D.P., Triantakonstantis, D.P., Kollias, V.J., 2002. Spatial prediction of two soil properties using topographic information. Global NEST Journal, 4(1): 41-49.

Karadoğan, S., Çağlıyan, A., Durmuş, E., 2008. Ergani (Diyarbakır) çevresinde kuvaterner'de meydana gelen drenaj değişiklikleri ve bölge jeomorfolojisine etkileri. Ulusal Jeomorfoloji Sempozyumu, 20-23 Mart, Çanakkale, s. 1-12.
Lindsay, W.L., Vlek, P.L.G., Chien, S.H., 1989. Phosphate minerals. In: JB Dixon and SB Weed (Eds.), Minerals in Soil Environment, 2nd edn. Soil Science Society of America, pp. 1089-1130.

Mali, S.S., Naik, S.K., Bhatt, B.P., 2016. Spatial variability in soil properties of Mango Orchards in Eastern Plateau and Hill Region of India. Vegetos-An International Journal of Plant Research, 29(3): 7479.

Nelson, D.W., Sommers, L., 1982. Total carbon, organic carbon, and organic matter1. Methods of Soil Analysis, Part 2- Chemical and Microbiological Properties (Methodsofsoilan), pp: 539-579.

O'Halloran, I.P., Kachanoski, R.G., Stewart, J.W.B., 1985. Spatial variability of soil phosphorus as influenced by soil texture and management. Canadian Journal of Soil Science, 65(3): 475-487.

Olsen, S.R., Sommers, L.E., 1982. Phosphorus. In Methods of Soil Analysis Part 2. In: A.L. Page, R.H. Miller and D.R. Keeney (Eds). Chemical and Microbiological Properties of Phosphorus. American Society of Agronomy and Soil Science Society of America Madison, pp. 403-430.

Pedrera-Parrilla, A., Van De Vijver, E., Van Meirvenne, M., Espejo-Pérez, A.J., Giráldez, J.V., Vanderlinden, K., 2016. Apparent electrical conductivity measurements in an olive orchard under wet and dry soil conditions: Significance for clay and soil water content mapping. Precision Agriculture, 17(5): 531545.

Presley, D.R., Ransom, M.D., Kluitenberg, G.J., Finnell, P.R., 2004. Effects of thirty years of irrigation on the genesis and morphology of two semiarid soils in Kansas. Soil Science Society of America Journal, 68(6): 1916-1926.

Rhoades, J.D., Chanduvi, F., Lesch, S., 1999. Soil Salinity Assessment, Methods and Interpretation of Electrical Conductivity Measurements. Food and Agriculture Orginization of the United Nations, Rome, Italy.

Roger, A., Libohova, Z., Rossier, N., Joost, S., Maltas, A., Frossard, E., Sinaj, S., 2014. Spatial variability of soil phosphorus in the Fribourg canton, Switzerland. Geoderma, 217-218: 26-36.

Sabeti, H., Moradzadeh, A., Ardejani, F.D., Azevedo, L., Soares, A., Pereira, P., Nunes, R., 2017. Geostatistical seismic inversion for non-stationary patterns using direct sequential simulation and co-simulation. Geophysical Prospecting, 65(1): 25-48.

Salvati, L., Zitti, M., Perini, L., 2016. Fifty Years on: Long-term Patterns of Land Sensitivity to Desertification in Italy. Land Degradation and Development, 27(2): 97-107.

Suarez, D.L., 1995. Carbonate chemistry in computer programs and application to soil chemistry. Soil Science Society of America, Special Publication, 42: 53-53.

Tan, K.H., Dowling, P.S., 1984. Effect of organic matter on CEC due to permanent and variable charges in selected temperate region soils. Geoderma, 32(2): 89101. 
Tripathi, R., Nayak, A.K., Shahid, M., Raja, R., Panda, B.B., Mohanty, S., Kumar, H., Lal, B., Gautam, P., Sahoo, R.N., 2015. Characterizing spatial variability of soil properties in salt affected coastal India using geostatistics and kriging. Arabian Journal of Geosciences, 8(12): 10693-10703.

Truog, E., 1947. Soil reaction influence on availability of plant nutrients. Soil Science Society of America Journal, 11(C): 305-308.

Usowicz, B., Lipiec, J., 2017. Spatial variability of soil properties and cereal yield in a cultivated field on sandy soil. Soil and Tillage Research, 174: 241-250.

Uzun, C., 2013. Farklı yaşlardaki volkanik materyal üzerinde oluşan toprakların ayrışma oranlarının belirlenmesi. Doktora tezi, Selçuk Üniversitesi Fen Bilimleri Enstitüsü, Konya.

Vasu, D., Singh, S.K., Sahu, N., Tiwary, P., Chandran, P., Duraisami, V.P., Ramamurthy, V., Lalitha, M., Kalaiselvi, B., 2017. Assessment of spatial variability of soil properties using geospatial techniques for farm level nutrient management. Soil and Tillage Research, 169: 25-34.
Wang, Y.Q., Shao, M.A., 2013. Spatial variability of soil physical properties in a region of the Loess Plateau of PR China subject to wind and water erosion. Land Degradation and Development, 24(3): 296-304.

Webster, R., Oliver, M.A., 2007. Geostatistics for Environmental Scientisits. Second Edition. John Wiley and Sons Limited, Chichester, England.

Weindorf, D.C., Zhu, Y., 2010. Spatial variability of soil properties at Capulin Volcano, New Mexico, USA: Implications for sampling strategy. Pedosphere, 20(2): 185-197.

Wilding, L.P., Bouma, J., Goss, D.W., 1994. Impact of Satial Variability on Interpretative Modelling. In: R.B. Bryant and R.W. Arnold (Eds.). Quantitative Modeling of Soil Forming Processes. Soil Science Society of American Jouirnal Special Publication, Madison Wisconsin, USA, pp. 65-75.

Yang, F., Zhang, G., Yin, X., Liu, Z., 2011. Field-scale spatial variation of saline-sodic soil and its relation with environmental factors in Western Songnen Plain of China. International Journal of Environmental Research and Public Health, 8(2): 374-387. 